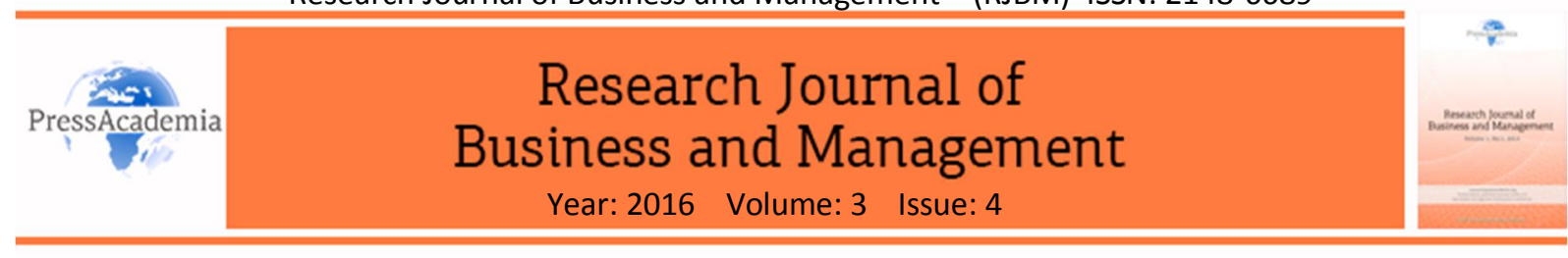

\title{
EXAMINING THE EFFECT OF CULTURAL DIFFERENCES MEASURING WITH CULTURAL INTELLIGENCE SCALE (CQS) ON EMPLOYEES' JOB SATISFACTION IN MULTI-CULTURAL COMPANIES
}

\section{DOI: 10.17261/Pressacademia.2016.350}

\author{
Acelya Telli ${ }^{1}$, Cemal Zehir $^{2}$ \\ ${ }^{1}$ Yildiz Technical University. acelya.telli@hotmail.com \\ ${ }^{2}$ Yildiz Technical University. c.zehir@yildiz.edu.tr
}

\begin{abstract}
In recent years, multiculturalism and management of cultural differences issues have begun to gain importance with globalization process and these issues become to two of main research topics in literature. These topics especially have associated with the cultural intelligence which has become the focus of much research. Within the framework of these issues, this study was conducted with an aim to examine the effect of cultural differences on job satisfaction in MNCs with cultural intelligence subscales. With this purpose, the survey was prepared which comprised of three parts (demographical questions, Cultural Intelligence Scale (CQS) questions and Minnesota Job Satisfaction Scale questions). The survey of this study was conducted on 100 employees working in different firms operating in different industries in Turkey. The obtained data from the questionnaires were analyzed through the SPSS statistical packaged software. The analyses results revealed that both dimensions of cultural intelligence had effect on all dimensions of job satisfaction.
\end{abstract}

Keywords: Cultural differences, multiculturalism, job satisfaction, multicultural companies,cultural intelligence. JEL Classification: F23, J28, M14.

\section{INTRODUCTION}

Today, especially in multicultural companies, cultural differences management, cross-cultural adaptation of employees and other personnel qualifications about culture have great importance for employees to work efficiently each other. Types of cultural differences and their importance for multicultural companies have started to take place in literature with Hofstede's (1980) cultural studies. He classified and examined cultures with some criteria as collectivism, force distance, avoidance from uncertainty, masculinity/femininity and long range accordance, and compared countries each other. As Hofstede, Trompenaars and Humpton-Turner also examined cultures with seven different dimensions and their oppositions called as universalism/particularism, individualism/communitarianism, specific/diffuse, neutral/emotional, achievement/ascription, sequential time/synchronous time, internal direction/outer direction (Bakan, 2006: 469-470). Another comparative study about culture was carried out by Hall called as "low culture/high culture". Hall described low culture with individualism and estrangement, in contrast high culture with communitarianism and good relations between people (Hall, 1976: 36).

The concept of "cultural differences" was described as differences between expectations of societies, which have their own cultural standards on their values, beliefs, things and communications styles, from each other and their common senses directing to their environment (Huseyinova, 2006: 34). Also, Thomas and Inkson (2005: 6) explained main causes of cultural differences as social cultural values, speaking styles, educational systems and life standards. On the other hand, Özgür (2007: 26-43) classified these differences with a SWOT and PEST analysis for a company. The author described strengths and weaknesses (internal business analysis) with opportunities and treats (external factors analysis) of cultural differences. In addition, he explained cultural differences with national conscious, level of welfare, religious and lingual differences, value system conflict, short-long range accordance, level of education, gender and low-high culture. Also, Hunopries and 
Grice (1995: 17) predicted that individualism was taken over with globalization and as a result of this situation, added-value which was provided by individuals and different groups at co-works had increased to incorporate both social and structural equity in organizations.

Cultural differences has started to gain importance in 1960s when cultural values come into prominence in international management and then in 1990s that subject began to be examined as "Diversity Management" in America (Sürgevil and Budak, 2008: 67; Ng and Earley, 2006). Especially in $21^{\text {st }}$ century, multinational companies have started to develop lots of management strategies for understanding and managing these cultural differences. Accordingly, these companies have taken actions about adaptation of different cultures for replying demands related with cross-cultural issues both in their companies. Particularly, it is observed that in multi-cultural organizations and societies, the management of cultural differences has become to be supported with both theorical and practical studies. With this aim, lots of companies develop a lot of strategies to create an area in which employees will respect to one another and work accordantly with each other. These strategies can be listed as multiculturalism, cultural synergy, cultural bluntness (Dilek, 2014: 32-34).

Multiculturalism (Mercan, 2016: 3) emerges from organizations in which employees from two or more different cultures work together. Also, Connerley and Pedersen (2005: 3) expressed that multiculturalism focused on being accessible to positive sides of all cultures and using the knowledge to create new and logical interactions. In contrast with differentiation in management strategies, cultural synergy is described as an integrative approach. This concept aims to destroy or minimize the current or possible negative effects of cultural differences and increase possible advantages of these differences (Ehtiyar, 2003: 70-71). Another strategy which is called cultural bluntness is a term which is used for employees overlooking, non-acceptive and unwilling to adoption attitudes about cultural differences. Therefore, there is a suspicion about efficiency of this approach (Dilek, 2004: 34).

Cultural diversity management in multicultural working areas, it is required that qualifications of employees can be used effectively (Gültekin and Ulukan, 2012: 93). In recent years we can see the best distinct example for managing cultural differences in assessment of recruitment process in multinational companies. These companies evaluate candidates with cultural adaptation as a competence criterion. Therefore, multinational companies have started to compete against their rival firms for incorporating candidates which adopt in multicultural area. Accordingly, researches on cultural competencies have been increased for maintaining relations in intercultural communication effectively in multinational companies and a need for research on this topic has emerged (Thomas and Inkson, 2005:6; Earley and Mosakowski, 2004: 139; Harris, 2006: 43-44; Tan, 2004: 19-21; Yeşil, 2010: 164). For cultural diversity management, with the idea that employees who work together in companies should have intercultural communication competencies and skills, it has become necessary to explain intercultural communication and intercultural differences, so that, an intercultural competence has become one of the contributive competence to employees in multinational companies as well as other competences (Zorel, 2014: 123).

Both theorical and practical studies on cultural competencies show that the concept of "Cultural Intelligence" (CQ) is a specific field and there is a need for intensifying studies on field researches rather than theorical or conceptual studies. Therefore, with the aim of contributing to cultural diversity management which takes a big value for multicultural companies, the effect of cultural differences on job satisfaction in multi-cultural companies were examined with using Cultural Intelligence Scale (CQS) and Minnesota Job Satisfaction Scale and eight general questions related with this issue. In field research part of this study, the survey was prepared as forty-eight questions and applied on a hundred participants working in different companies operating in different industries. Also, participants were selected with simple random sampling method. In the light of findings, results were interpreted in conclusion part.

The results showed that all sub-dimensions of cultural intelligence (especially dimension of the behavioral intelligence) is related to all the sub-dimensions of job satisfaction (internal and external satisfaction) and four hypothesis $(\mathrm{H} 1, \mathrm{H} 2, \mathrm{H} 3, \mathrm{H} 4)$ in this research are supported. It has been found that analyze the results of the research are consistent with the results obtained from the analysis related to cultural intelligence and job satisfaction in literature. 


\section{LITERATURE REVIEW AND HYPOTHESES}

\subsection{Cultural Intelligence}

In a research on employees, who have some competences about related with culture for managing cultural differences, required cultural competences were explained as being flexible and innovative, cultural adaptation, global leadership and looking from other perspectives. Accordingly, a reply had been started to search about a question for why some people were more effective and successful than others in intercultural areas and the concept of cultural intelligence was appeared as the answer (İşçi, Söylemez and Kaptanoğlu, 2013:3-4).

Earley and Ang (2003) developed a conceptual model related with a study was put forward by Sternberg and Detterman in 1986 related with cultural intelligence, then they described the concept of cultural intelligence as an ability to have influence on areas which have cultural diversity in a multicultural group or organization by employees (Mercan, 2016: 4). As for another description by Earley and Mosakovski (2004: 139-140) in a Harvard Business Review, cultural intelligence was explained that "understanding and interpreting behaviors of individuals have some unconventional and unreceptive gestures and mimics like who friends are or come from same cultures. (anlamadım) Also Ang et al. (2007) explained the cultural intelligence as "a competence of working effectively in different cultural areas" and summarized their previous both theorical and practical studies. As a result of these studies, they created "Cultural Intelligence Scale" (CQS), then it was transformed to Turkish form and gained to literature by Şahin and Gürbüz in 2013.

It is emphasized that cultural intelligence is required to build good relationships with individuals each other (Triandis, 2006; Johnson et al., 2006), also it is important to be able to sensitive to other employees and work with them harmoniously in cross-cultural areas (Tan, 2004). Hence, lots of classifications to explain and understand cultural intelligence. For instance, Earley and Mosakovski (2004) examined cultural intelligence with three sub-scales, which are mental, physical and emotional cultural intelligence. Also, Earley and Ang (2003) classified cultural intelligence as four sub-scales which are meta-cognitive, cognitive, behavioral and motivational cultural intelligence. Similarly, Van Dyne and Ang (2005) explained cultural intelligence with four sub-scales which are strategy-related, knowledge-related, motivation-related and behavior-related cultural intelligence. Even cultural intelligence is explained with some sub-scales, it is not wrong to say that all subscales are related with each other (Van Dyne, Ang and Livermoore, 2010: 131-138). In this study, cultural intelligence is examined with four sub-scales which are classified by Earley and Ang in 2003.

Meta-cognitive cultural intelligence as the first sub-scale of cultural intelligence includes some mental processes using by individuals to understand and internalize cultural knowledge and controls of these processes. Also meta-cognitive cultural intelligence is described as a fact intended to cultural awareness in intercultural interaction processes of individuals with their cultural backgrounds. (Ang, Van Dyne, Koh, 2008: 17). Cognitive cultural intelligence as the second sub-scale of cultural intelligence explained individual's cultural knowledge of norms and practices with their education and experience. So, this sub-scale is vital for decision making and performance in cross-cultural areas, because it shows us cultural similarities and differences (Yeşil, 2009: 124, Yeşil, 2010: 159; Ang, Van Dyne, Koh, 2008: 17). Motivational cultural intelligence as the third subscale of cultural intelligence is described as an impulse, demand or attention of individuals to interact culturally each other in cross-cultural areas (Templer, Tay and Chandrasekar, 2006: 154). Behavioral cultural intelligence as the last sub-scale of cultural intelligence is described as competence provides to enact a suitable behavior towards individual's verbal and nonverbal behavioral actions. This cultural intelligence is very important to understand nonverbal behaviors are called silent language (Ang, Van Dyne, Koh, 2008: 17; Earley and Ang, 2003: 81).

To explain the relationship with cultural differences and cultural intelligence with its' sub-scales, many researches were carried out. For instance, Cox and Blake (1991: 54) set forth the importance of the competence to manage cultural differences and gain competitive advantages for both individuals and companies in the study. Also, Ersoy and Ehtiyar (2015: 42-60) put forward the significant contributions of subscales of cultural intelligence to manage cultural differences and create positive reactions in their study which is about the role of cultural intelligence to manage cultural differences in accommodation sector. Moreover, 
many researchers (Earley and Ang, 2003; Earley and Mosakowski, 2004; Ang and Van Dyne, 2008; Yeşil, 2009; Şahin, 2011) who explained one of the most important strategies on the management of cultural differences is cultural intelligence emphasized the importance of cultural intelligence on managing multi-cultural groups and organizations, recognizing, understanding colleagues and work harmoniously each other.

Earley and Peterson (2004) put forward the role of cultural intelligence on intercultural training. Moreover, Van Dyne, Ang and Livermoore (2010) studied on the relationship between global leadership and cultural intelligence subscales. Also, Ang et al. (2006) searched for the relationship between cultural intelligence subscales and the types of personality. Similarly, with the aim of examining the relationship between cultural intelligence levels and competences of cultural difference management, Dilek (2014) made an empirical analysis on 310 employees working at A Class travel agencies. In the light of results, a relationship in a positive way was observed between cultural intelligence levels and competences of cultural difference management. So, when cultural intelligence levels of managers increase, competences of cultural difference management increase too.

\subsection{Job Satisfaction}

Job satisfaction is one of the most investigated subjects since 1930s, because of its' direct and indirect effects on both for individuals' work-life balance and for organizations to be able to provide efficiency of organizational activities. Yet, a decrease in job satisfaction levels of employees is not only effects the employee's efficiency, performance and motivation; but also create negative results for financial situation of organization (Adler and Golan, 1981: 544-554; Clegg, 1983: 88-101; Tharenou, 1993: 269-287). Today, a logical relationship between job satisfaction and employee's motivation and performance, labor turnover rate, work absenteeism and organizational citizenship behavior increased both companies' and researchers' interests to search interactions these subjects each other (Gürbüz and Yüksel, 2008: 179). So, it is continued to be explored especially in organizational behavior and other many related fields in literature (Robbins, 1998: 142; Judge et al., 2002: 25-26).

There are lots of descriptions as both conceptual and practical to explain job satisfaction. For instance, job satisfaction can be described as individuals' self-satisfaction for their works (Luthans, 1992: 114). Also, we can explain this concept with an emotion emerges from the difference between individuals' expectations and actual results (Sudak and Zehir, 2013: 148). So, it can be said that job satisfaction is the main indicator of employees' happiness levels from their works (Vieira, 2005: 39).

Job satisfaction is examined with two different theorical approaches which are concept theories and expectation theories (Lawler III, 1994: 84). In concept theories, job satisfaction is identified with performance and divided to internal and external sides of it. Internal job satisfaction is related with central and internal sides of employees' duties; in contrast external job satisfaction is related with external sides of their jobs (Judge vd., 2002: 27). In expectation theories, job satisfaction is correlated with motivation. As concept theories we can examine Maslow's Hierarchy of Needs Theory, Herzberg's Two Factor Theory, McClelland's The Need for Achievement Theory and Alderferg's ERG Theory. Also, for expectation theories we can look for Victor Vroom's Expectation Theory, Lawler and Porter's The Theory of Operant Conditioning, J. Stacy Adams' Equity Theory and Locke's Goal Theory (Köroğlu, 2012: 277).

With the aim of examining the relationship between job satisfaction and intelligence, there were lots of researches have been made on both types of intelligence and types of personality. For instance, Goleman (1995) studied the relationship between job satisfaction and emotional intelligence and in the light of the study, he found that emotional intelligence ensured to have the power of competition to employees, and also job satisfaction provided to be successful for employees at work. Similarly, Thomas, Tram and O'hara (2006) examined the relationship between job satisfaction and emotional intelligence of both managers and employees in nine franchise restaurant in food sector. As a result of this study, they found that emotional intelligences of managers and employees were in a positive and logical relationship with both job satisfaction and performance. Also, Sudak and Zehir (2013) studied on the relationship between the types of personality and job satisfaction. As a result, they found that emotional intelligence had increased work-life balance and influenced job performance and job satisfaction in a positive way. Alternatively, Şahin (2011) examined the 
effects of leaders' cultural intelligence on staff's organizational citizenship behavior and job satisfaction analyzing with Hierarchical Validation Model. As a result of the study, relationship was found in a positive way between the leaders' cultural intelligence and staff's organizational citizenship behavior and job satisfaction.

Diemer (2016) studied on the relationship between cultural intelligence and work outcomes of expatriates in China and as a result of empirical analysis, a positive and logical relationship was determined between expatriates' job satisfaction and subscales of cultural intelligence, especially motivational cultural intelligence. Barakat, Lorenze, Ramsey and Cretoiu (2015) also examined the relationship between cultural intelligences and job satisfaction levels of global managers working in international companies in Brazil. Authors of this study reached similar results with Diemer (2016) and they found that a positive-directed relationship between cultural intelligence and job satisfaction and also they observed that high cultural intelligence had increased job satisfaction levels of these global managers.

\subsection{Development of Hypotheses}

In the light of the literature study on cultural intelligence and job satisfaction related with cultural differences and their management, four hypotheses are set to determine whether or not each cultural intelligence subscale effect the employees' job satisfaction in multicultural companies. These are:

$H_{1}=$ Cultural intelligence affects the employees' internal job satisfaction positively in multicultural companies.

$\mathrm{H}_{2}=$ Cultural intelligence affects the employees' external job satisfaction positively in multicultural companies.

\section{DATA AND METHODOLOGY}

In this survey it is aimed to examine the effect of cultural differences on employees' job satisfaction in multicultural companies with cultural intelligence subscales which are meta-cognitive cultural intelligence, cognitive cultural intelligence, behavioral cultural intelligence and motivational cultural intelligence. To test the propositions, a field survey using questionnaires was conducted.

The survey of this study is conducted on 100 employees who are still working in multicultural companies in different sectors in Turkey. The survey consists of three parts. At first part, questions were asked about demographic characteristics (gender, age, education situation, foreign language skills, total work experience in multicultural companies, total work experience in current workplace, work experience in abroad) to form descriptive statistical data. At the second part of survey, questions were asked to measure cultural intelligence and Cultural Intelligence Scale (CQS) was used. At the last part of the survey, questions were asked to measure job satisfaction of employees. Due to the fact that Minnesota Job Satisfaction Scale is the most known and used continuously in graduate theses. (Özsoy, Uslu, Karakiraz and Aras, 2014: 241-242), It was used to measure job satisfaction in this study. Data of Questionnaires obtained from the firm and those questionnaires were analyzed through the SPSS statistical packet program and two proposed relations with hypotheses were tested through factor and correlation analyses. Finally, a regression analysis was also conducted to test the hypotheses and to define to direction of relations.

\section{FINDINGS AND DISCUSSIONS}

At the first part of this survey consists of eight demographical questions to measure descriptive statistical data. When examining some of these questions results, for instance looking to gender distribution between participants, it can be seen that 43 percent of participants consists of women and 57 percent is men. Also, 69 percent of participants' education level is graduate degree, 22 percent is master degree, and 5 percent graduated from high school and 4 percent has doctoral degree. When examining work experience in abroad of participants, it can be seen that 49 percent of participants have not any work experience in abroad, 21 percent of participants have only one work experience in abroad and the rest of them (30 percent) have two or more work experience in abroad. Similarly, when looking to total work experience in multicultural companies of participants, it is revealed that 50 percent of participants have 0-3 year, 23 percent of participants have 4-6 year, 16 percent of participants have 7-10 year and the rest of them (11 percent) have 10 or more year work experience in multicultural companies. Moreover, as examining the results of total work experience in current workplace of participants, 67 percent of participants have 0-3 year, 18 percent of participants have 4-6 year, 8 
percent of participants have 7-10 year and the rest of them (7 percent) have 10 or more year work experience in their current workplace.

At the second part of this survey, to measure four dimensions (meta-cognitive, cognitive, motivational, and behavioral) of cultural intelligence, 20 items of Ang et al. (2007) and adopted to Turkish form by Şahin et al. (2013) is used. Also at the third part of this survey, to measure two dimensions (internal satisfaction, external satisfaction) of job satisfaction, Minnesota Job Satisfaction short form (20 item-scales) of Weis et al (1967) is used. However, 5 items are deleted or because they showed a weak loading or loaded two different factor. Overall, 43 items are used to measure job satisfaction and cultural intelligence. Those items with factor loadings can be seen on the Table 1 . Also as it has been seen on the Table 2, the Cronbach's Alpha values for each factors exceeds 0,87 , which indicates the reliability of scales used in that survey.

Table 1:Results of Factor Analysis

\begin{tabular}{|c|c|c|c|c|c|c|}
\hline & 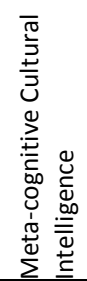 & 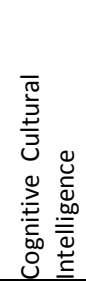 & 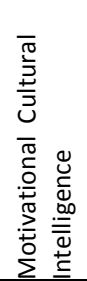 & 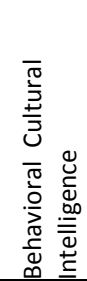 & 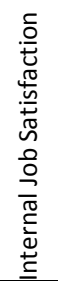 & 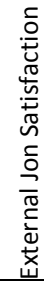 \\
\hline \multicolumn{7}{|l|}{ CULTURAL INTELLIGENCE } \\
\hline $\begin{array}{l}\text { 1. I am conscious of the cultural knowledge I use when interacting with people by different } \\
\text { cultural backgrounds. }\end{array}$ & ,724 & & & & & \\
\hline $\begin{array}{l}\text { 2. I adjust my cultural knowledge as I interact with people from a culture that is unfamiliar to } \\
\text { me. }\end{array}$ & ,861 & & & & & \\
\hline 3. I am conscious of the cultural knowledge I apply to cross-cultural interactions. & ,839 & & & & & \\
\hline $\begin{array}{l}\text { 4. I check the accuracy of my cultural knowledge as I interact with people from different } \\
\text { cultures. }\end{array}$ & 824 & & & & & \\
\hline 5. I know the legal and economic systems of other cultures. & & ,686 & & & & \\
\hline 6. I know the rules (e.g. vocabulary, grammar) of other languages. & &, 520 & & & & \\
\hline 7. I know the cultural values and religious beliefs of other cultures. & &, 531 & & & & \\
\hline 8. I know the marriage systems of other cultures. & & ,742 & & & & \\
\hline 9. I know the arts and crafts of other cultures. & & ,850 & & & & \\
\hline 10. I know the rules of expressing nonverbal behaviors in other cultures. & & ,723 & & & & \\
\hline 11. I enjoy interacting with people from different cultures. & & & 667 & & & \\
\hline 12. I am confident that I can socialize with locals in a culture that is unfamiliar to me. & & & 680 & & & \\
\hline 13. I am sure I can deal with the stresses of adjusting to a culture that is new to me. & & & ,713 & & & \\
\hline 14. I enjoy living in cultures that are unfamiliar to me. & & & ,822 & & & \\
\hline 15. I am confident that I can get accustomed to the shopping conditions in a different & & & ,695 & & & \\
\hline 16. I change my verbal behavior (e.g. accent and tone) when a cross-cultural interaction & & & & 694 & & \\
\hline requires it. & & & & ,678 & & \\
\hline $\begin{array}{l}\text { 17. I use pause and silence differently to suit different cross-cultural situations. } \\
\text { 18. I vary the rate of my speaking when a cross-cultural situation requires it. }\end{array}$ & & & & ,827 & & \\
\hline 18. I vary the rate of my speakıng when a cross-cultural situation requires it. & & & & ,702 & & \\
\hline $\begin{array}{l}\text { 19. I change my nonverbal behavior when a cross-cultural interaction requires it. } \\
\text { 20. I alter my facial expressions when a cross-cultural interaction requires it. }\end{array}$ & & & & ,705 & & \\
\hline
\end{tabular}




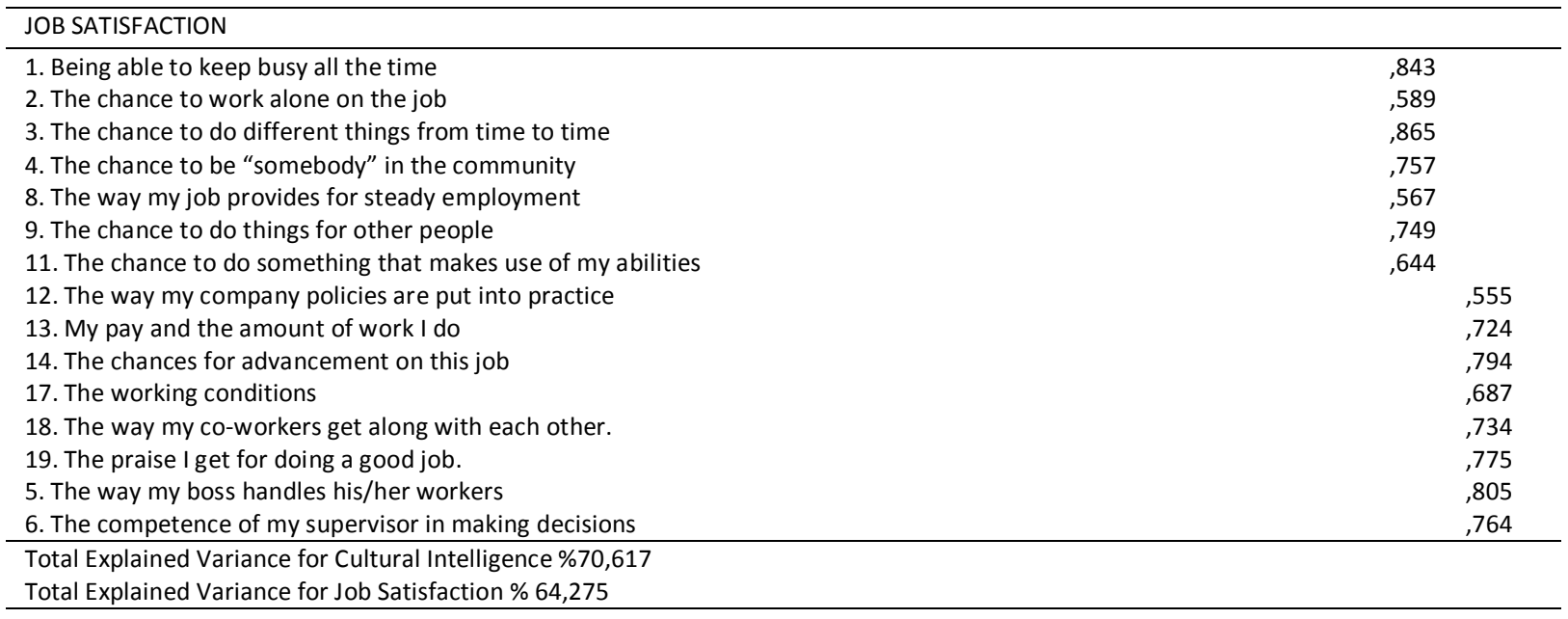

Table 2: Cronbach Alpha Values and Source of Scales

\begin{tabular}{lllll}
\hline Concepts & Number of Items & Scale Format & Cronbach Alpha & Scale Sources \\
\hline Meta-Cognitive Cultural Intelligence & 4 & LRFa & 0,871 & Ang et al. (2007) \\
Cognitive Cultural Intelligence & 6 & LRFa & 0,890 & Ang et al. (2007) \\
Motivational Cultural Intelligence & 5 & LRFa & 0,859 & Ang et al. (2007) \\
Behavioral Cultural Intelligence & 5 & LRFa & 0,906 & Ang et al. (2007) \\
Internal Job Satisfaction & 7 & LRFb & 0,900 & Weis et al. (1967) \\
External Job Satisfaction & 8 & LRFb & 0,916 & Weis et al. (1967) \\
\hline
\end{tabular}

Notes: a LRF - Likert Response Format (Five point: $1=$ strongly disagree to $5=$ strongly agree)

b LRF - Likert Response Format (Five point: 1=very low to 7 = very high)

Table 3 shows the correlation among job satisfaction dimensions (internal job satisfaction and external job satisfaction) and dimensions of cultural intelligence (meta-cognitive cultural intelligence, cognitive cultural intelligence, motivational cultural intelligence and behavioral cultural intelligence). When we examined the Table 3, it can be seen that in both 0,01 and 0,05 significance levels, a strong correlation was found among all dimensions of cultural intelligence (especially behavioral cultural intelligence) and internal job satisfaction in a positive way. In addition, the Table 3 shows even there is not found a strong correlation among meta-cognitive cultural intelligence and external job satisfaction, the rest three dimensions of cultural intelligence which are cognitive cultural intelligence, motivational cultural intelligence and especially behavioral cultural intelligence correlated strong with external job satisfaction in a positive way.

Table 3: Correlations Between Cultural Intelligence and Job Satisfaction

\begin{tabular}{|c|c|c|c|c|c|c|}
\hline Variables & Meta-Cognitive & Cognitive & Motivational & Behavioral & Internal & External \\
\hline $\begin{array}{l}\text { Meta-cognitive } \\
\text { Cognitive }\end{array}$ &, $427^{* *}$ & & & & & \\
\hline Motivational &, $467^{* *}$ &, $562^{* *}$ & & & & \\
\hline Behavioral & $310^{* *}$ &, $750^{* *}$ & $650^{* *}$ & & & \\
\hline Internal & $254^{*}$ & $347^{* *}$ & $244^{*}$ &, $385^{* *}$ & & \\
\hline External & 139 & $367^{* *}$ & $270^{* *}$ & $390^{* *}$ & $709^{* *}$ & \\
\hline
\end{tabular}

** Correlation is significant at the 0,01 level (2-tailed); ${ }^{*}$ Correlation is significant at the 0,05 level (2-tailed)

When we examine the Table 4 to see the regression analysis results, it can be seen that cultural intelligence (includes meta-cognitive cultural intelligence, cognitive cultural intelligence, motivational cultural intelligence and behavioral cultural intelligence) have significant effect on both internal and external satisfaction scale of job satisfaction. According to the Table 4, cultural intelligence $(\beta=, 387 ; p<0,001)$ have significant relationship to internal job satisfaction. Similarly, cultural intelligence $(\beta=, 372 ; p<0,001)$ also have significant relationship to 
external job satisfaction. As a result of the regression analysis, $1 \mathrm{~A}$ and $1 \mathrm{~B}$ regression analysis results support all hypotheses ( $\mathrm{H}_{1}$ and $\mathrm{H}_{2}$ hypotheses).

Table 4: Regression Analysis Results of the Effect of Cultural Intelligence on Job Satisfaction

\begin{tabular}{|c|c|c|c|c|c|c|c|}
\hline $\begin{array}{c}\text { Regression } \\
\text { Model }\end{array}$ & $\begin{array}{c}\text { Independent } \\
\text { Variables }\end{array}$ & $\begin{array}{c}\text { Dependent } \\
\text { Variables }\end{array}$ & $\begin{array}{c}\text { Standardized } \\
\beta\end{array}$ & Sig. & Adjusted R2 & F Value & Model Sig. \\
\hline 1A & Cultural Intelligence & $\begin{array}{c}\text { Internal Job } \\
\text { Satisfaction }\end{array}$ &, 387 &, 000 &, 141 & 17,221 &, 000 \\
\hline 2B & Cultural Intelligence & $\begin{array}{c}\text { External Job } \\
\text { Satisfaction }\end{array}$ &, 372 &, 000 &, 472 & 15,772 &, 000 \\
\hline
\end{tabular}

In accordance with the regression analyses results, research model is being shaped as it has been shown at Figure 1 below:

Figure 1: Final Research Model

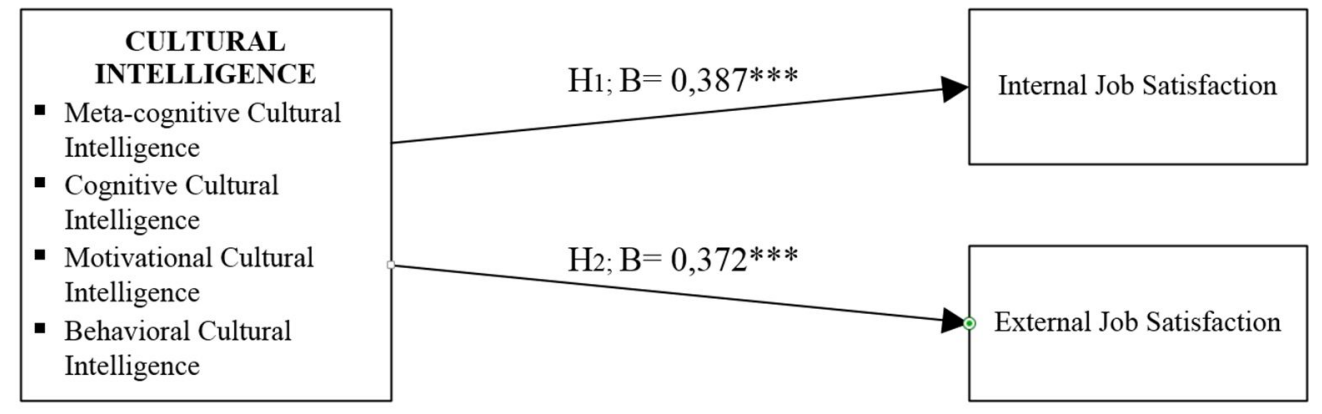

$* * * ; p<0,001$

\section{CONCLUSION}

This survey was conducted on employees working in different multicultural companies operating in different sectors in Turkey to measure the effect of cultural intelligence on employees' job satisfaction. The most striking result was emerged from the data that the strongest correlation is between behavioral intelligence and all dimensions of job satisfaction (both internal and external job satisfaction). In addition, all hypotheses $\left(\mathrm{H}_{1}, \mathrm{H}_{2}\right.$, $\mathrm{H}_{3}$ and $\mathrm{H}_{4}$ ) were fully supported with the results of the survey. These findings are consistent with other researches on cultural intelligence and job satisfaction. Although there are many researches examining both cultural intelligence and job satisfaction (Şahin, 2011; Barakat et al., 2015; Diemer, 2016) in literature; through this survey, the effects of cultural differences measuring with Cultural Intelligence Scale (CQS) only on employees' job satisfaction in multi-cultural companies in Turkey was examined for the first time, which differentiates this survey from others. On the other hand, this survey was conducted on different firms operating in different industries; so findings might not be specialized when determining cultural differences to all types of organizations. Thus, it is recommended that further researches can be conducted on specific industries or companies which face with some problems to manage their cultural differences. 


\section{REFERENCES}

Adler, S. \& Golan, J. (1981). Lateness As A Withdrawal Behavior, Journal of Applied Psychology, 66, pp.544-554.

Ang, S. Dyne, L. V., Koh, C., Chandrasekar, N. A. (2007), Cultural Intelligence: Its Measurement and Effects on Cultural Judgment and Decision Making, Cultural Adaptation and Task Performance, Management and Organization Review, 3 (3), pp.335-371.

Ang, S. \& Dyne, L. V. (2008). Conceptualization of Cultural Intelligence: Definition, Distinctiveness, and Nomological Network, in Ang, S and Dyne, L. V. (Ed.) Handbook on Cultural Intelligence: Theory, Measurement and Applications, NY: M.E. Sharpe, Armonk.

Ang, S. \& Dyne, L. V. (2005). Cultural Intelligence: An Essential Capability for Individuals in Contemporary Organizations, Global EDGE, https://globaledge.msu.edu/newsAndViews/views/papers/cultural intelligence.pdf (28.3.2016).

Barakat, L. L., Lorenz, M.P., Ramsey, J. R., Cretoiu, S.L. (2015). Global Managers: An Analysis Of The Impact Of Cultural Intelligence On Job Satisfaction And Performance, International Journal of Emerging Markets, 10(4), pp.781-800.

Clark, A. E. (1996). Job Satisfaction in Britain, British Journal of Industrial Relations, 34(2), pp.189-217.

Clegg, C. W. (1983). Psychology of Employee Lateness, Absence and Turnover: A Methodological Critique and An Empirical Study, Journal of Applied Psychology, 68, pp.88-101.

Connerley, M. L. \& Pedersen, P. B. (2005), Leadership in a Diverse and Multicultural Environment. USA: Sage Publications.

Cox, T. and Blake, S. (1991). Managing cultural diversity: Implications for organizational competitiveness. Academy of Management Executive, 5(3), pp.45-56.

Çarıkçı, I.H. (2000). Personality Characteristics and Its' Organizational Results in Employees' Job Satisfaction - A Research on Supermarket Supermarket Staff, The Journal of The Faculty of Economics and Administrative Sciences of Süleyman Demirel University, 5(2), pp.155-168.

Diemer, B. J. (2016). The Relationship Between Cultural Intelligence and Work Outcomes of Expatriates in China, Doctoral Thesis, Walden University.

Dilek, N. K. (2014). The Efficiency of Cultural Intelligence in Management Process of Cultural Differences: A Field Research on Class Tourism Agency Managers, Master Thesis, Muğla Sıtkı Koçman University, Social Sciences Institute, The Department of Tourism Management, Muğla.

Earley, P.C. \& Ang, S. (2003). Cultural Intelligence: Individual Interactions Across Cultures. Paloalto: Stanford University Press.

Earley, P. C. \& Mosakowski, E.(2004). Cultural Intelligence, Harvard Business Review.

Earley, P.C. \& Peterson, R.S. (2004). The Elusive Cultural Chameleon: Cultural Intelligence As A New Approach To Intercultural Training For The Global Manager. Academy of Management Learning and Education, 3, pp.100-115.

Ehtiyar, R. (2003). Cultural Synergy: An Conceptual Examination for International Companies, The Journal of The Faculty of Economics and Administrative Sciences of Akdeniz University, 3 (5), pp.66-78

Ersoy A. \& Ehtiyar V.R. (2015). The Role of Cultural Intelligence in Management of Cultural Differences: A Research on Turkish Managers and Expatriates, Anatolia: The Journal of Tourism Researches, 26, pp.42-60.

Goleman, D. (1995). Emotional Intelligence, New York: Bantam Books.

Gültekin, Z. \& Ulukan, C. (2012). Management of Cultural Differences in Multinational Teams, The Journal of Anadolu University Social Sciences, 12(1), pp.89-102.

Gürbüz, S. \& Yüksel, M. (2008). Emotional Intelligence at Working Area: The Relationship with Job Performance, Job Satisfaction, Organizational Citizenship Behavior and Some Demographical Characteristics, The Journal of Dogus University, 9(2), pp.174-190.

Harris, M.M. (2006). Cultural Skill: An Emerging Construct for the 21st Century, Global Forum, 43(3).

Hofstede G. (1980). Cultural consequences: International differences in work related values. Newbury Park, CA: Sage.

Humpries, M. \& Grice, S. (1995). Equal Employment Opportunity and The Management of Diversity, Journal of Organizational Change, 8 , pp.17-32.

Hüseyinova, K. (2006). Cultural Differences and Its' Effects on International Trade, Master Thesis, Marmara University, Social Sciences Institute, The Department of Business Management, Istanbul.

İşçi, E., Söylemez, Ö., Kaptanoğlu, A.Y. (2013). Cultural Intelligence and A Research For Determining Cultural Intelligence Level in Hospitals, The Journal of Kafkas Üniversitesi The Faculty of Economics and Administrative Sciences, 4 (5), pp.1-18.

James P., Johnson, J. P., Lenartowicz, T., Apud, S. (2006). Cross-Cultural Competence In International Business: Toward A Definition And A Model, Journal of International Business Studies, 37, pp.525-543. 
Judge, Timothy A., Sharon Parker, Amy E. Colbert, Daniel Heler, Remus llies (Eds.). (2002). Job Satisfaction: A Cross-Cultural Review, Handbook of Industrial, Work \& Organizational Psychology, Volume 2: Organizational Psychology, SAGE Publications, London, Thosand Oaks, New Delhi, Second Edition, pp.25-52.

Köroğlu, Ö. (2012). Determination Of The Relationship Between The Levels of Intrinsic and Extrinsic Job Satisfaction with Level of General Job Satisfaction: An Investigation On Tour Guides, The Journal of Dogus University, 13(2), pp. 275-289.

Lawler III, E. E. (1994). Motivation In Work Organizations. First Edition. San Francisco: JosseyBass Publishers.

Luthans, F. (1992). Organizational Behavior, New York:Mc Graw -Hill Press.

Mercan, N. (2016). A Research For The Relationship With Cultural Intelligence and Intercultural Sensitivity in Multicultural Areas, The Journal of The Faculty of Economics and Administrative Sciences of Niğde University, 9(1), pp.1-13.

Ng, Kok-Yee., Earley, P. C. (2006). Culture+Intelligence: Old Constructs, New Frontiers, Group \& Organisation Management, 31(1), pp.4-19.

Özsoy, E., Uslu, O., Karakiraz, A., Aras, M. (2014). Scale Using In Measuring Job Satisfaction: An Examination on Graduate Theses, The Journal of Business Researches, 6(1), pp.232-250.

Robbins, S.P. (1998). Organizational Behavior: Concepts, Controversies, Applications, Eighth Edition (International Edition), Prentice HallInternational, New Jersey.

Sudak, M. \& Zehir, C. (2013). A Research on Types of Personality, Emotional Intelligence and Job Satisfaction, The Journal of Management Sciences, 11(22), pp.141-165.

Sürgevil, O. \& Budak, G. (2008). A Research for Determining Management of Differences Approach Styles of Companies, The Journal of Dokuz Eylül University Social Sciences Institute, 10 (4), pp.65-96.

Şahin, F. (2011). The effect of Leaders' Cultural Intelligence on Employees' Oganizational Citizenship Behavior with Job Satisfaction, The Journal of Defence Sciences, 10(2), pp.80-104.

Şahin, F., Gürbüz, S., Köksal, O. \& Ercan, Ü. (2013). Measuring Cultural Intelligence in the Turkish context, International Journal of Selection and Assessment. 21(2), pp.135-144.

Sternberg, R.J. \& Detterman, D.K. (1986). What is intelligence? Contemporary viewpoints on its nature and definition. Norwood, NJ: Ablex.

Tan, Joo-Seng, (2004). Issues \& observations: Cultural intelligence and the global economy, Leadership in Action, 24(5), pp.19-21.

Templer, K, J., Tay, C, Chandrasekar, N. A. (2006), Motivational Cultural Intelligence, Realistic Job Preview, Realistic Living Condition preview, and Crosscultural adjustment. Group \& Organization Management; 31(1), pp.154-173.

Thomas, D. C. \& Inkson, K. (2005). Cultural Intelligence: people skills for a global workplace. Consulting to Management, 16 (1).

Thomas, Sy, Tram, S., O'hara, L.A. (2006). Relation Of Employee and Manager Emotional Intelligence To Job Satisfaction and Performance, Journal of Vocational Behavior, 68(3), pp.461-473.

Thorenou, P. (1993). A Test of Reciprocal Causality for Absenteeism, Journal If Organizational Behavior, 14, pp.269-287.

Triandis, H. C. (2006). Cultural intelligence in organisations, Group\& Organisations Management, 31(1), pp.20-26.

Trompenaars, F. \& Hampden-Turner, C. (1997). Riding the waves of culture. Nicholas Brealey Publishing, London.

Van Dyne, L., Ang, S., Livermore, D. (2010). Cultural intelligence: A pathway for leading in a rapidly globalizing world. K. M. Hannum, B. McFeeters, \& L. Booysen (Eds) in, Leading across differences: Cases and perspectives (pp.131-138). San Francisco, CA: Pfeiffer.

Vieira, J. A. C. (2005). Skill mismatches and job satisfaction, Economic Letters, 89, pp.39-47.

Yeşil, S. (2009). The Management of Cultural Differences and An Alternative Strategy: Cultural Intelligence, The Journal of The Faculty of Economics and Administrative Sciences of Kahramanmaraş Sütçü Imam University, 11(16), pp.100-131.

Yeşil, S. (2010). Cultural Intelligence for Global Companies in $21^{\text {st }}$ Century, The Journal of Social Sciences Institute of Çukurova University, 19 (2), pp.147-168.

Zorel, F.I. (2014). Intercultural Competence As A Qualification That International Company Employees Have To Have, The Journal of International Social Research, 7(30), pp.122-135. 